\title{
LEMBAGA PEREKONOMIAN DESA DAN BADAN USAHA MILIK DESA SEBAGAI UPAYA PENGUATAN EKONOMI DESA
}

\author{
Suartini ${ }^{1}$ dan Nizla Rohaya ${ }^{2}$ \\ 1 tini.look@gmail.com dan ${ }^{2}$ nizla.rohaya@gmail.com \\ 1Universitas Al-Azhar Indonesia \\ ${ }^{2}$ Universitas Muhammadiyah Tangerang \\ Correspondence Email: awihaber@gmail.com
}

\begin{abstract}
ABSTRAK Strengthening the village economy has become the government's discussion as evidenced by the issuance of several laws and regulations relating to the formation of village economic institutions such as the Village Credit Institution in Bali and Lumbung Pitih Nagari in West Sumatra coupled with the establishment of village-owned enterprises which began to be regulated in 1999 until now. Village-owned enterprises are regulated in Law Number 6 of 2014 concerning Villages. The two economic institutions, both LPD and LPN, are able to exist until now and support the village economy so that the strengthening of the village economy is formed by the presence of these two institutions. The BUMDesa that was established at this time has also been able to strengthen the village economy with the form of a business entity that until now the villages are competing to advance the Village BUM and try to strengthen the village economy through the Village BUM. The method used in this research is doctrinal research as referred to by Terry Hutchinson. Normative legal research does not recognize field research because what is being studied is legal materials so that it can be said to be a libbary based focusing on reading and analysis of primary and secondary material. . The result of this research is that strengthening the village economy can be done through village economic institutions and village-owned enterprises because both are the pillars of the village economy so that they are able to prosper the village.
\end{abstract}

KEYWORDS: Economic institutions, village-owned enterprises, village economy

\section{PENDAHULUAN}

Kemandirian desa sejak dahulu menjadi tujuan utama pengembangan potensi desa yang tujuan utamanya adalah prioritas dari pembangunan desa baik dari sisi ekonomi, sumber daya manusia, khususnya sumber daya alamnya.(Gai et al., 2020; Malik, 2019) Desa memiliki potensi yang tidak seragam sehingga untuk memajukan desa tidaklah dapat dibentuk keseragaman karena desa memiliki potensi yang berbeda-beda ada yang mengutamakan potensi wisatanya, ada yang mengutamakan potensi pertanian, perkebunan dan peternakan ada juga desa yang tidak memiliki 
potensi sumber daya alam yang dapat dikelola, hal inilah yang menyebabkan tidak dapat diberlakukan secara seragam baik terhadap peraturan maupun kegiatan perekonomian masyarakat desa.(Falaqi \& Sulistiono, 2020)

Lembaga perekonomian desa sudah dibentuk sejak tahun 1904 untuk tujuan pemenuhan ekonomi masyarakat desa. Pada tahun 1904 didirikan Bank Desa, yang selanjutnya dikenal sebagai Badan Kredit Desa (BKD).(Karsidi, 2019) Hal ini dimaksudkan agar pengawasan oleh Algemene Volkcrediet Bank (AVB yang kemudian menjadi BRI) lebih mudah. Badan Kredit Desa (BKD) ini merupakan asset desa yang pengelolaannya terpisahkan dari kekayaan desa yang lainnya, sehingga apabila terjadi kerugian pada BKD tidak dapat ditutup dengan kekayaan desa yang lain.(Biduri et al., 2021; Mukhammad, 2019) BKD merupakan lembaga keuangan di pedesaan yang berasal dari rakyat dan untuk rakyat itu sendiri. BRI hanyalah sebagai pengawas dan pembina dalam kegiatan operasionalnya sebagai kepanjangan delegasi wewenang Bank Indonesia.(Baskara, 2013) Keberadaan BKD yang sampai saat ini masih diakui dan bertahan dalam kegiatan perekonomian di pedesaan sangatlah berarti baik bagi masyarakat maupun bagi Pemerintah Desa itu sendiri.(Biduri et al., 2021)

Bank Kredit Desa hadir pada tahun 1986 dimulai sejak jaman kolonial Belanda, atas dasar keadaan ekonomi desa di wilayah Banyumas yang memprihatinkan akibat kegagalan panen secara luas yang dikarenakan musim kemarau panjang, banjir dan serangan hama. (Astuti, 2011)Melihat kondisi tersebut, asisten Residen Banyumas (De Wolf Van Westerrode) membentuk Kelompok Swadaya Masyarakat (KSM) untuk mengatasi keadaan tersebut. Hasil rembug desa KSM pada tahun 1897 memutuskan untuk mendirikan 250 buah Lumbung Desa sebagai Badan Kredit Desa di wilayah Banyumas.

Lumbung-lumbung desa yang pada awalnya berjalan dengan lancar dan dapat membantu kesulitan ekonomi masyarakat di pedesaan, dalam perjalanannya banyak yang mengalami kegagalan/kebangkrutan. Hal tersebut dikarenakan banyak masyarakat yang meminjam di lumbung-lumbung desa yang ada tidak bisa mengembalikan pinjamannya tersebut. Kebanyakan dari mereka masih mengalami kesulitan ekonomi. Dari banyaknya lumbung-lumbung desa yang didirikan, hanya beberapa saja yang masih bisa bertahan. Guna menyelamatkan keberadaan 
lumbung-lumbung desa tersebut, maka AVB (Algemene Volkscrediet Bank) memberikan pinjaman modal agar tetap dapat membantu kesulitan ekonomi masyarakat pedesaan.(Mukhammad, 2019)

Lembaga Dana Kredit Pedesaan (LDKP) yang didirikan awal periode 1970 untuk mengelompokkan lembaga keuangan mikro non-bank yang terdapat disetiap propinsi. LDKP merupakan istilah generik untuk beberapa jenis lembaga kredit dan simpanan kecil yang ada, sesuai dengan daerah masing-masing, di banyak propinsi.(Baskara, 2013) Pada akhir periode 1970an, sebanyak hampir 300 lembaga kredit seperti ini terdapat di Indonesia. Pada saat itu lembaga-lembaga ini diperlakukan sebagai lembaga keuangan non-bank, dan berdasarkan UndangUndang Perbankan Tahun 1967 tidak memenuhi persyaratan untuk memperoleh kredit likuiditas dari Bank Indonesia (BI), dan oleh sebab itu dana dari lembaga ini harus dihimpun dari sumber lain. Lembaga-lembaga ini juga tidak diijinkan untuk memobilisasi dana dalam bentuk simpanan dan tidak terikat pada aturan suku bunga dari BI, sehingga mereka dapat menentukan suku bunga sendiri. Hingga pada saat ini masih banyak yang berdiri di Indonesia, diantaranya yang berdiri pada awal periode tersebut adalah Badan Kredit Kecamatan (BKK) di Jawa Tengah, Lembaga Perkreditan Kecamatan (LPK) di Jawa Barat, Lumbung Pitih Nagari (LPN) di Sumatera Barat yang kepemilikannya oleh lembaga adat.(Husnan, 1999; Prastuti, 2011)

Eksistensi Lembaga Perkreditan Desa di Bali lebih maju dan sampai sekarang masih eksis bahkan maju dan berkembang sebagai lembaga perkonomian desa yang menopang masyakarat desa adatnya, sedangkan Lumbung Pitih Nagari eksistensinya sudah tidak ditemukan hanya satu yang masih bertahan yaitu Lumpung Pitih Nagari di Limau Manis Sumatera Barat, permasalahan eksistensi Lumbung Pitih Nagari adalah karena ada reformasi Lumbung Pitih Nagara beralih menjadi Bank Perkreditan Rakyat.(Arka, 2016; Kurniasari, 2007)

Undang-Undang Nomor 1 tahun 2013 Tentang Lembaga Keuangan Mikro (LKM) mengakui keunikan dan kearifan lokal sehingga ada dua LKM yaitu tidak tunduk Undang-Undang tersebut yaitu LPD di bali dan LPN di Sumatera Barat.(Harefa, 2017) Kedua Lembaga tersebut adalah Lembaga Perkreditan Desa (LPD) di Bali dan Lumbung Pitih Nagari (LPN) di Sumatera Barat yang telah 
terbentuk sebelum Undang-Undang tersebut lahir sehingga menurut UU LKM, LPD dan Lumbung Pitih Nagari tersebut tak harus tunduk pada UU lantaran keberadaannya diakui berdasarkan hukum adat.

Badan Usaha Milik Desa yang sering disebut dengan BUMDes atau BUM Desa adalah sebuah lembaga usaha desa yang dikelola oleh pemerintah desa juga masyarakat desa tersebut dengan tujuan untuk memperkuat perekonomian desa dan dibentuk berdasarkan kebutuhan dan potensi yang ada di desa tersebut.(Ridlwan, 2014) BUMDes merupakan sebuah badan usaha yang mampu membantu masyarakat dalam segala hal antara lain memnuhi kebutuhan seharihari, menjadi peluang usaha atau lapangan pekerjaan, menambah wawasan masyarakat desa.(Agunggunanto et al., 2016)

Badan Usaha Milik Desa yang dimaksud dalam undang-undang desa adalah untuk desa administratif atau desa otonom yang bukan merupakan desa adat karena desa adat di Indonesia telah eksis dalam lembaga perekonomian desa yang berbentuk Lembaga Perkreditan Desa (LPD) di Desa Pakraman Bali dan Lumbung Pitih Nagari (LPN) di Sumatera Barat.(Baskara, 2013) Keadaan desa adat di Indonesia yang telah memiliki lembaga ekonomi dan berlangsung hingga kini merupakan gambaran bahwa spirit dari undang-undang desa untuk pendirian badan usaha milik desa diperuntukkan untuk desa lainnya selain desa adat, karena desa adat sudah memiliki lembaga perekonomian yang hingga kini masih eksis sebagai sarana pembangunan ekonomi desa.(Sila, 2014)

Lembaga perekonomian desa dan badan usaha desa adalah hal yang sudah ada sejak zaman dahulu yang memang menjadi prioritas bagi pemgembangan ekonomi desa dapat dibuktikan yang hingga kini eksis adalah di Bali dengan LPD (Lembaga Perkreditan Desa) dan di Sumatera Barat dengan LPN (Lumbung Pitih Nagari) yang lalu pada desa adminitratif atau otonom diatur mengenai pendirian Badan Usaha Milik Desa 


\section{METODE PENELITIAN}

Penelitian ini tergolong penelitian hukum normatif yaitu penelitian yang dipersamakan dengan penelitian doctrinal research sebagaimana dimaksud oleh Terry Hutchinson penelitian hukum normatif tidak mengenal penelitian lapangan (field research) karena yang diteliti adalah bahan-bahan hukum sehingga dapat dikatakan sebagai library based focusing on reading and analysis of primary and secondary material. (Muhdar, 2019; Muhdlor, 2012) Penelitian hukum hanya memfokuskan perhatiannya terhadap permasalahan hukumnya saja yaitu terhadap kajian penerapan aturan hukum yang didukung dengan teori dan konsep-konsep di bidang hukum dan fakta hukum yang memunculkan ketidakterpaduan antara kajian teoritis dan penerapan hukum positif atau ketidakterpaduan antara keadaan yang diharapkan (das sollen) dengan kenyataan (das sein). Pendekatan penelitian yang digunakan dalam penelitian ini adalah pendekatan historis (historical approach), pendekatan Undang-Undang (statute approach), dan pendekatan konseptual (conceptual approach).(Amiruddin \& Zainal, 2006) Pendekatan yang digunakan dalam penelitian ini untuk dapat mendeskrpsikan lembaga perekonomian dan badan usaha desa dalam rangka penguatan ekonomi desa.

\section{ANALISA DAN PEMBAHASAN}

Badan Usaha Milik Desa sebenarnya sudah ada jauh sebelum Undang-Undang Nomor 6 Tahun 2014 Tentang Desa dan diatur sebelumnya pada Undang-Undang Nomor 22 Tahun 1999 Tentang Pemerintahan Daerah lahir, tetapi Badan Usaha Milik Desa sebelumnya dalam bentuk lembaga perekonomian desa yang bergerak dalam pemenuhan ekonomi desa melalui simpan pinjam atau dikenal dengan lembaga perkreditan desa. Lembaga perekonomian yang masih eksis hingga saat ini sebagai badan usaha yang memiliki khas desa di Indonesia yaitu Lembaga Perkreditan Desa di Bali dan Lumbung Pitih Nagari di Sumatera Barat, walaupun Lumbung Pitih Nagari banyak yang bereformasi menjadi Bank Perkreditan rakyat namun masih ada satu yang masih eksis yaitu Lumbung Pitih Nagari di Limau Manis Sumatera Barat. Lembaga Perkreditan Desa di Bali adalah Badan Usaha Milik Desa Pakraman yang hingga kini masih eksis bahkan sangat menopang perekonomian masyarakat desa di Bali. 


\section{LPD di Bali}

LPD adalah lembaga keuangan komunitas masyarakat yang sangat berbeda dengan lembaga keuangan pada umumnya dan LPD merupakan bentuk usaha milik desa Pakraman yang sifat khas dan landasan bentuk badan usaha dan pengelolaannya serta fungsi nyata dalam masyarakat. LPD merupakan badan hukum yang sosio-ekonomi religius. Pondasi penyangga kebudayaan Bali adalah keberadaan desa Pakraman. Ketentuan Pasal 18B ayat (2) mengatur tentang pengakuan dan keberadaan "masyarakat hukum adat" dari berbagai kelompok masyarakat yang mempunyai susunan asli yang ada dalam wilayah Republik Indonesia.

Masyarakat adat di Bali, sesuai dengan sifat dan fungsinya merupakan lembaga yang bersifat sosial-religius dan sosio-ekonomi. Masyarakat adat mempunyai tujuan organisasi, personalia dan manajemen (lembaga adat) yang jelas. Pimpinan adat merupakan unsur lembaga yang menjalankan segala ketentuan dan kebijakan lembaga, baik tertulis maupun tidak tertulis. Salah satu garis besar tugas dan fungsinya adalah terkait dengan pengelolaan kekayaan desa adat untuk kesejahteraan masyarakat desa adat.

Awal pendirian Lembaga Perkreditan Desa di Bali dimulai dengan diterbitkannya surat Keputusan Gubernur Kepala Daerah Tingkat Propinsi Bali No.972 Tahun 1984 tentang pendirian LPD di Provinsi Daerah Tingkat I Bali dan secara historis gagasan pembentukan LPD di Bali bermula dari penyelenggaraan Seminar Nasional tentang Kredit Desa di Semarang pada tangal 20-21 Februari 1984 atas dasar surat Menteri Dalam Negeri No.412.21/2144/Bangda perihal persetujuan rencana diskusi dan seminar perkreditan desa. Hasil seminar inilah yang menjadi tindak lanjut Pemerintah Propinsi Bali untuk mendiskusikan lebih dalam berfokus pada pembuatan rencana program perkreditan pedesaan sebagai bagian dari program pemberdayaan ekonomi rakyat pedesaan, pengembangan perekonomian dan peningkatan kesejahteraan masyarakat Bali.

Hasil seminar menjadi acuan pemerintah Bali mengkaji dan mendalami kredit pedesaan, serta melalui serangkaian diskusi maka diputuskan Lembaga Kredit Pedesaan untuk Propinsi Bali diberi nama Lembaga Perkreditan Desa, 
yang didirikan desa Pakraman sekaligus sebagai pengelola dan penanggungjawabnya. Dipilihnya Desa Pakraman sebagai basis pendirian lembaga perkreditan desa karena:

a. Desa Pakraman merupakan lembaga tradisional yang telah mengakar dan dihormati oleh masyarakat pedesaan terutama oleh Kramanya.

b. Desa Prakraman telah mempunyai aturan baik secara tertulis maupun tidak tertulis

c. Desa Prakraman merupakan suatu lembaga tradisonal bersifat kelompok yang didasarkan pada geografis adat, dimana terdapat interaksi sosial yang terjadi sehari-hari sehingga mengakibatkan tumbuhnya rasa kesatuan dan kerjasama alamiah sebagai perwujudan gotong royong

d. Desa Prakraman mempunyai kewajiban dan beban tanggung jawab yang cukup besar bila dibandingkan dengan hak yang dimiliki

Berkenaan dengan hal tersebut pemerintah Provinsi Bali mengatasinya melalui pengembangan lembaga perekonomian desa, khususnya lembaga keuangan desa adat. Lembaga tersebut adalah Lembaga Perkreditan Desa (LPD) yaitu suatu lembaga yang dibentuk dan dikelola dan dimiliki oleh Desa Prakraman, yang landasan hukumnya adalah Perda Provinsi Bali Nomor 3 Tahun 2007 sebagaimana telah diubah dengan Nomor 3 Tahun 2017 tentang LPD.

LPD sebagai suatu lembaga keuangan dalam aktivitasnya ditunjukkan dengan ciri-ciri: merupakan milik desa Prakraman, dibentuk dan dikelola oleh desa Pakraman, menyelenggarakan fungsi-fungsi kelembagaan keuangan komunitas desa Prakraman seperti menerima dan menghimpun dana dari krama desa dan memberikan pinjaman hanya kepada krama desa dan menyelenggarakan fungsi usaha sebagai lembaga usaha keuangan internal desa Prakraman atau sejauh-jaunya antar desa Prakraman.

LPD bukan badan hukum karena memiliki sifat yang khas sehingga aturan yang ada dalam perda hanya menyebutkan LPD merupakan bentuk 
usaha milik desa Pakraman dan bukan merupakan perseroan terbatas karena bentuk tanggungjawabnya adalah tanggung renteng dan berdasarkan sifat dasar dan landasan konstitusionalnya maka bentuk badan hukum yang dapat diberikan kepada LPD adalah bentuk Badan Hukum Sosio-Ekonomi Religius.

Karakteristik LPD adalah bercorak komunal berbasis masyarakat hukum adat dalam kehidupan skala dan niskala desa Pakraman yang dasar pendiriannya dari hukum adat tertulis yang disebut awig-awig/Perarem dan inisiatif pendirian berasal dari dan untuk Krama (warga) menjadi Druwe (milik) desa Pakraman serta berbasis pada kehidupan ekonomi keuangan komunal masyarakat hukum adat di desa Pakraman. Desa Pakraman mempunyai unsur-unsur yang terangkum dalam Tri Hita Karana. Unsur yang pertama adalah unsur parahiyangan (hal-hal yang berhubungan dengan agama Hindu), unsur pawongan (aktifitas warga desa yang beragama Hindu/Krama desa), unsur terakhir adalah unsur palemahan (wilayah desa yang berupa karang ayahan desa dan karang gunakarya sesuai ajaran Hindu). Tugas dan wewenang utama desa pakraman adalah melaksanakan ajaran agama Hindu dan menegakkan hukum adat bali diwilayahnya. Tugas dan wewenang lainnya yaitu berkoordinasi dengan desa dinas dan pihak berwenang lainnya untuk menciptakan kasukertan (kedamaian) diwilayahnya.

\section{LPN di Sumatera Barat}

Lumbung Pitih Nagari yang biasa di sebut dengan LPN adalah lembaga keuangan mikro berbasis adat yang lahir dari kearifan lokal nagari-nagari (desa) yang ada di Sumatera Barat sejak jaman sebelum kemerdekaan . LPN berfungsi mendorong perekonomian masyarakat yang ada di Nagari melalui pemberian modal, simpan pinjam maupun berbagai produk lainnya, selaian berfungsi sebagai lembaga ekonomi LPN juga berfungsi menggerakkan aspek sosial budaya masyarakat dengan membantu acara adat seperti pengangkatan datuk, acara pernikahan dan kegiatan lainnya di nagari juga berfungsi sosial seperti pembangunan mesjid balai pemuda dan lain lain. Keberadaan Lumbung Pitih Nagari telah ada jauh sebelum masuknya lembaga keuangan 
mikro formal seperti Bank Perkreditan Rakyat (BPR), BRI Unit Desa dan lembaga keuangan mikro lainnya ke pelosok-pelosok Sumatera Barat. LPN bersumber pada lembaga keuangan informal milik masyarakat yaitu lumbung padi nagari dan kelompok arisan yang ditujukan untuk penyimpanan padi ketika panen berhasil dan pemberian pinjaman modal dari sesama dan bagi sesama masyarakat dalam suatu nagari. LPN dibangun berdasarkan nilai-nilai luhur gotong royong, kekeluargaan dan saling membantu yang sudah ada sejak lama di Mingakabau.

Nagari adalah bagian yang tidak terpisahkan dari identitas dan basis kehidupan masyarakat Minangkabau Sumatera Barat, nagari adalah seperangkat mekanisme adat untuk mengatur segala bentuk hubungan sosial seperti sistem pemerintahan, sistem ekonomi, hubungan antar manusia dan hubungan antar manusia dengan alam. Nagari diatur dengan prinsip tali tigo sapilin yaitu peraturan antar hukum adat, syari'at Islam dan hukum negara (hukum positif atau undang-undang).

Lumbung Pitih Nagari didirikan berdasarkan Peraturan Daerah tingkat I Propinsi Sumatera Barat Nomor 1 tahun 1982 tentang Lumbung Pitih Nagari, yang kemudian disahkan dengan Keputusan Menteri Dalam Negeri No. 142.23.918 menetapkan ada 4 (empat) tujuan dari pendirian LPN yaitu:

a. Mendorong pembangunan ekonomi rakyat desa atau kelurahan melalui tabungan terarah serta penyaluran modal yang efektif

b. Membentuk dan menghimpun modal untuk pembangunan di desa /keluarahan.

c. Mewujudkan suatu badan usaha simpan pinjam yang berfungsi sosial dengan menggunakan prinsip-prinsip ekonomi berdasarkan pancasila dan

d. Menciptakan pemerataan dalam kesempatan berusaha bagi warga dan tenaga kerja pedesaan dan kelurahan.

Perubahan status LPN Bank BPR, sangat disesali oleh masyarakat Sumatera Barat, dengan peralihan status tersebut LPN yang menjadi BPR perkembangannya tidak bagus bahkan cenderung banyak yang mati atau tidak 
mampu melaksanakan operasional dan kredit macet mencapai 11 persen, sementara aturan dalam lembaga keuangan mikro adalah harus di bawah 5 persen, dan itulah menyebabkan perubahan jumlah LPN yang menjadi BPR sebanyak 29 unit yang kini masih eksis namun masih ada LPN yang hingga kini masih bertahan dengan LPN tanpa merubah statusnya menjadi BPR yaitu LPN yang masih tersisa hanya satu unit yakni LPN di Limau Manis di Kecamatan Pauh Padang Sumatera Barat.

Keberadaan LPN Limau Manis telah berlangsung lama yang hingga saat ini masih eksis dan tidak bereformasi kedalam bentuk Bank Perkreditan Rakyat yaitu dari tahun 1988 hingga kini. LPN Limau Manis tetap berdiri sebagai LPN karena mempertimbangkan keadaan masyarakat adat di nagari tersebut jika mereka merubah statusnya menjadi BPR maka masyarakat akan kesulitan untuk melakukan peminjaman karena akan dibebani oleh persyaratan yang rumit padahal pinjaman masyarakat itu kadang tidak terlalu besar. Kekhawatiran lainnya adalah jika LPN Limau Manis Berubah menjadi BPR maka jati diri dari pendirian LPN itu akan hilang yaitu lembaga perekonomian desa yang menggunakan prinsip sosial ekonomi dan budaya pada masyarakat desa akan hilang karena akan mengedepankan prinsip ekonomi saja yaitu menghasilkan keuntungan yang sebesar-besarnya.

Keberadaan LPN Limau Manis yang hanya ada satu di Sumtaera Barat ini merupakan salah satu lembaga perekonomian desa yang berbasis adat yang masih eksis hingga saat ini, dalam pengelolaan LPN mendapatkan dana dari tabungan masyarakat dan untuk kepentingan masyarakat dan prinsip pengelolaan mereka menggabungkan pengelolaan bank dan koperasi yang pada prinsip mempermudah masyarakat untuk mendapatkan bantuan keuangan melalui LPN. Permasalahan dalam LPN seperti kredit macet dll diselesaikan dengan musyawarah dan akan diselesaikan secara adat dan kekeluargaan khususnya jika ada permasalahan kredit macet dapat dilakukan parate eksekusi sesuai dengan musyawarah dan juga melibatkan mamak pada setiap sukunya. 
LPN Limau Manis tediri dari masyarakat adat dengan lima suku yang berbeda yaitu: suku piliang, tanjung, chaniago, melayu, jambak. Lima suku tersebut memilih mamaknya yang akan terlibat dalam seluruh masalah masyarakat baik dalam pinjaman maupun pengembalian dana. Selama 25 tahun eksis LPN Limau Manis mencapai aset 20 Milyar dengan mengumpulkan atau menghimpun dana masyarakat lalu menyalurkan melalui pinjaman yang berbasis masyarakat adat. Keadaan LPN Limau Manis yang hanya satu ini diharapkan dapat menjadi contoh bagi desa atau nagari lain di Sumatera Barat serta dukungan dari pemerintah daerah dengan membuat aturan baru yang melindungi lembaga perekonomian desa dengan mempertahankan ciri khas nagari/desa atau jati dirinya dengan menambahkan modal serta melakukan pembinaan dan kegiatan yang pada intinya untuk menguatkan lembaga perkekonomian desa yaitu LPN di Sumatera Barat

\section{BUM Desa}

BUM Desa dibentuk oleh Pemerintah Desa untuk mendayagunakan segala potensi ekonomi, kelembagaan perekonomian, serta potensi sumber daya alam dan sumber daya manusia dalam rangka meningkatkan kesejahteraan masyarakat desa. Undang-Undang Nomor 6 Tahun 2014 Tentang Desa adalah peraturan pelaksana BUM Desa dan ditindaklanjuti oleh lahirnya Peraturan Pemerintah Nomor 43 Tahun 2014 Tentang Peraturan Pelaksanaan Undang-Undang Nomor 6 Tahun 2014 Tentang Desa serta Peraturan Menteri Desa, Pembangunan Daerah Tertinggal, Dan Transmigrasi Nomor 4 Tahun 2015 Tentang Pendirian, Pengurusan Dan Pengelolaan, Dan Pembubaran Badan Usaha Milik Desa.

Pengaturan bentuk Badan Usaha Milik Desa dalam Undang-Undang Nomor 6 Tahun 2014 diatur dalam Pasal 1 Angka 6 Undang-Undang Nomor 6 Tahun 2014 Tentang Desa yang memberikan pengaturan mengenai pengertian BUM Desa itu sendiri, yaitu "Badan usaha yang seluruh atau sebagian besar modalnya dimiliki oleh Desa melalui penyertaan secara langsung yang berasal dari kekayaan desa yang dipisahkan guna mengelola aset, jasa pelayanan, dan usaha lainnya untuk sebesar-besarnya kesejahteraan 
masyarakat desa". Pengertian tersebut serupa dengan pengertian BUM Desa yang diberikan oleh peraturan pelaksana dari Undang-Undang Nomor 6 Tahun 2014 Tentang Desa, yaitu Pasal 1 Angka 7 Peraturan Pemerintah Nomor 43 Tahun 2014 Tentang Peraturan Pelaksanaan Undang-Undang Nomor 6 Tahun 2014 Tentang Desa j.o Pasal 1 Angka 2 Peraturan Menteri Desa, Pembangunan Daerah Tertinggal, Dan Transmigrasi Nomor 4 Tahun 2015 Tentang Pendirian, Pengurusan Dan Pengelolaan, Dan Pembubaran Badan Usaha Milik Desa.

Pasal 7 Peraturan Menteri Desa, Pembangunan Daerah Tertinggal, dan Transmigrasi Nomor 4 Tahun 2015 Tentang Pendirian, Pengurusan dan Pengelolaan, dan Pembubaran Badan Usaha Milik Desa, diatur mengenai bentuk Organisasi BUM Desa sebagai berikut: "BUM Desa dapat terdiri dari unit-unit usaha yang berbadan hokum sebagaimana dimaksud pada ayat (1) dapat berupa lembaga bisnis yang kepemilikan sahamnya berasal dari BUM Desa dan masyarakat. Dalam hal BUM Desa tidak mempunyai unit-unit usaha yang berbadan hukum, bentuk organisasi BUM Desa didasarkan pada Peraturan Desa tentang Pendirian BUM Desa, sebagaimana dimaksud dalam Pasal 5 ayat (3).

Bentuk badan hukum dari unit-unit usaha tersebut juga telah diatur secara tegas di dalam Pasal 8 Peraturan Menteri Desa, Pembangunan Daerah Tertinggal, Dan Transmigrasi Nomor 4 Tahun 2015 Tentang Pendirian, Pengurusan Dan Pengelolaan, Dan Pembubaran Badan Usaha Milik Desa, yang mengatur bahwa: "BUM Desa dapat membentuk unit usaha meliputi: Perseroan Terbatas sebagai persekutuan modal, dibentuk berdasarkan perjanjian, dan melakukan kegiatan usaha dengan modal yang sebagian besar dimiliki oleh BUM Desa, sesuai dengan peraturan perundang-undangan tentang Perseroan Terbatas; dan Lembaga Keuangan Mikro dengan andil BUM Desa sebesar 60 (enam puluh) persen, sesuai dengan peraturan perundangundangan tentang lembaga keuangan mikro."

Pendirian BUM Desa bertujuan:

a. Meningkatkan perekonomian Desa;

b. Mengoptimalkan aset Desa agar bermanfaat untuk kesejahteraan Desa; 
c. Meningkatkan usaha masyarakat dalam pengelolaan potensi ekonomi Desa;

d. Mengembangkan rencana kerja sama usaha antar desa dan/atau dengan pihak ketiga;

e. Menciptakan peluang dan jaringan pasar yang mendukung kebutuhan layanan umum warga;

f. Membuka lapangan kerja; meningkatkan kesejahteraan masyarakat melalui perbaikan pelayanan umum, pertumbuhan dan pemerataan ekonomi Desa; dan

g. Meningkatkan pendapatan masyarakat Desa dan Pendapatan Asli Desa.

Sebagai badan usaha BUM Desa berfungsi sebagai penguatan ekonomi desa serta mampu mewujudkan kemandirian desa, sudah banyak BUM Desa yang sudah maju dan tidak lagi mengandalkan dana desa untuk membangun atau memenuhi perekonomian desanya. Kemandirian dan penguatan ekonomi inilah yang menjadi cikal bakal penopang perekonomian pusat sehingga dapat menghindari urbanisasi atau perpindahan masyarakat desa ke kota.

\section{KESIMPULAN DAN SARAN}

Kesimpulan dalam penelitian ini adalah bahwa negara Indonesia sejak dulu sudah mengatur mengenai lembaga perekonomian desa baik khusus untuk desa adat maupun desa adminitratif yang mana baik lembaga perekonomian dan badan usaha milik desa memunculkan ciri khas sendirinya sebagai rekognisi dari kearifan lokal sehingga dapat dilihat beragamnya bentuk lembaga perekonomian dan juga badan usaha yang memiliki ciri pokok yaitu tidak hanya untuk kepentingan ekonomi semata tetapi juga kepentingan sosial menjadi tujuan utama Lembaga perekonomian desa dan badan usaha milik desa.

Saran terkait penelitian ini adalah agar pembuat kebijakan memperhatikan kearifan lokal sehingga dapat membuat aturan yang tidak mengutamakan keseragaman tetapi kebutuhan desa masing-masing yang tetap mengedepankan ciri sosio-ekonomi. 


\section{Referensi}

Agunggunanto, E. Y., Arianti, F., Kushartono, E. W., \& Darwanto, D. (2016). Pengembangan Desa Mandiri Melalui Pengelolaan Badan Usaha Milik Desa (Bumdes). Jurnal Dinamika Ekonomi \& Bisnis, 13(1).

Amiruddin, \& Zainal, A. (2006). Pengantar Metode Penelitian Hukum. PT. Raja Grafindo Persada.

Arka, I. W. (2016). Eksistensi Lembaga Perkreditan Desa dalam Pembangunan Desa Pekraman Sebagai Desa Wisata di Bali. Ganec Swara, 10(2), 78-84.

Astuti, Y. D. (2011). Strategi Promosi Perkreditan Pada Perusahaan Daerah Bank Perkreditan Rakyat Badan Kredit Desa Kabupaten Karanganyar.

Baskara, I. G. K. (2013). Lembaga Keuangan Mikro di Indonesia. Buletin Studi Ekonomi. Biduri, S., Maryanti, E., \& Pebrianggara, A. (2021). Eksistensi Kinerja BKD sebagai Unit Bumdes pada Desa Bligo Kec. Candi Kab. Sidoarjo. Studi Kasus Inovasi Ekonomi, $5(01)$

Falaqi, A., \& Sulistiono, E. (2020). Perencanaan Pengembangan Potensi Desa Dalam Upaya Peningkatan Ekonomi Desa Maduran.

Gai, A. M., Witjaksono, A., \& Maulida, R. R. (2020). Perencanaan dan Pengembangan Desa. Dream Litera Buana.

Harefa, M. (2017). Perkembangan, Tantangan, dan Perspektif Kebijakan Pengembangan Lembaga Perkreditan Desa (LPD) Bali Sebagai Intermediasi Keuangan. Kajian, 21(4), 339-357.

Husnan, M. (1999). PERUBAHAN BENTUK HUKUM BADAN KREDIT KECAMATAN MENJADI BANK PERKREDITAN RAKYAT MENURUT UNDANG1JNDANG NOMOR 7 
TAHUN1992 DAN IMPLIKASINYA TERHADAP KEGIATAN USAHA [PhD Thesis]. PROGRAM PASCASARJANA UNIVERSITAS DIPONEGORO.

Karsidi, R. (2019). PERAN DAN FUNGSI LEMBAGA KEUANGAN PEDESAAN.

Kurniasari, T. W. (2007). Lembaga Perkreditan Desa (LPD) dalam perspektif hukum:

Sebuah Lembaga Keuangan Adat Hindu penggerak usaha sektor informal di Bali. Jurnal Masyarakat Dan Budaya, 9(1), 54-78.

Malik, H. (2019). Bangun Industri Desa Selamatkan Bangsa: Strategi Pembangunan Industri Desa di Kabupaten Kaur, Bengkulu. PT Penerbit IPB Press.

Muhdar, M. (2019). Penelitian Doctrinal dan Non-Doctrinal, Pendekatan Aplikatif dalam Penelitian Hukum. Mulawarman University Press.

Muhdlor, A. Z. (2012). Perkembangan Metodologi Penelitian Hukum. Jurnal Hukum Dan Peradilan, 1(2), 189-206.

Mukhammad, A. (2019). ANALISIS TRANSFORMASI BADAN USAHA MILIK DESA (STUDI TRANSFORMASI BADAN KREDIT DESA WLAHAR WETAN MENJADI PT BPR BKD BANYUMAS) [PhD Thesis]. IAIN Purwokerto.

Prastuti, R. (2011). Peranan Badan Kredit Kecamatan (BKK) dalam Meningkatkan Usaha Sektor Informal Perdagangan di Wilayah Kecamatan Jebres Kota Surakarta Tahun 2010.

Ridlwan, Z. (2014). Urgensi BUMDes dalam Pembangunan Perekonomian Desa. Fiat Justicia Jurnal Ilmu Hukum Fakultas Hukum Universitas Lampung, 8(3), 424440.

Sila, M. A. (2014). Lembaga Keuangan Mikro dan Pengentasan Kemiskinan: Kasus Lumbung Pitih Nagari di Padang. MASYARAKAT: Jurnal Sosiologi, 1-19. 